\title{
Motivations for Pursuing an Engineering PhD and Perceptions of its Added Value: A U.S.-based Study
}

\author{
Jeremi S. London, Monica F. Cox, Benjamin Ahn, \\ Sara E. Branch, and Tasha Zephirin \\ Purdue University, West Lafayette, Indiana, USA
}

islondon@purdue.edu; mfc@purdue.edu; bahn@purdue.edu sbranch@psych.purdue.edu; tkzeph@purdue.edu

\section{Ana Torres-Ayala University of South Florida, Tampa, Florida, USA}

attorres@mail.usf.edu

\author{
Jiabin Zhu \\ Shanghai Jiao Tong University, \\ Shanghai City, China
}

¡iabin.emily.zhu@gmail.com

\begin{abstract}
Engineering doctor of philosophy $(\mathrm{PhD})$ holders possess expertise that is vital to addressing society's grand challenges, but the dismal number of U.S. citizens pursuing the degree suggests many are not convinced of its value. There are few studies that have explored what motivates people in other disciplines to pursue a $\mathrm{PhD}$, and not many of these were in the context of engineering. In this study, forty engineering PhD holders working in academia and industry in the U.S. described their motivations for earning an engineering $\mathrm{PhD}$ and the perceived added value of possessing the degree. The results of this study indicate that the motivations for pursuing an engineering $\mathrm{PhD}$ relate to career aspirations, prior success in graduate school, the influence of others, and intrinsic factors. Participants' discussions about the added value of an engineering $\mathrm{PhD}$ manifests itself in the form of career outcomes, attributes and skills, and positive responses from others. Few participants described the "added value" of a PhD as neutral or having limitations. Both motivational and added value factors vary by employment sector. The findings of this study have implications for engaging more students in pursuing doctoral engineering studies - both in U.S. institutions and doctoral engineering programs around the world.
\end{abstract}

Material published as part of this publication, either on-line or in print, is copyrighted by the Informing Science Institute. Permission to make digital or paper copy of part or all of these works for personal or classroom use is granted without fee provided that the copies are not made or distributed for profit or commercial advantage AND that copies 1) bear this notice in full and 2) give the full citation on the first page. It is permissible to abstract these works so long as credit is given. To copy in all other cases or to republish or to post on a server or to redistribute to lists requires specific permission and payment of a fee. Contact Publisher@InformingScience.org to request redistribution permission.
Keywords: Engineering education, motivation, value of $\mathrm{PhD}$, engineering $\mathrm{PhD}$

\section{Introduction}

Society's grand challenges surrounding healthcare, energy, and education are complex, interdisciplinary, and difficult to solve; and engineers play a vital role in addressing them (NAE, 2008b). Finding solutions to these challenges re- 
quires skilled researchers with disciplinary and adaptive expertise, proficiency at solving illstructured problems, and efficiency in the use of advanced technologies. Leaders in innovation are essential to addressing society's greatest needs and engineers who conduct research are often cited as such (NAE, 2005). Doctoral engineering education provides the training that prepares young people to meet these high expectations.

Very few U.S. citizens earn engineering PhDs. In the U.S., less than $1 \%$ of the population holds a doctoral degree at all (U.S. Census Bureau, 2012). Among the PhDs awarded by U.S. institutions in $2011,16 \%$ were in engineering (NSF, 2012d). That same year, $71 \%$ of the engineering $\mathrm{PhD}$ graduates pursued careers in industry, while less than $14 \%$ took positions in academia (NSF, $2012 \mathrm{~b}$ ). Approximately half (51\%) of the engineering doctorates awarded in 2010 went to foreign-born students (NSF, 2012c).

Many national reports highlight a shortage of engineers in the U.S. workforce (NAE, 2010; NRC, 2007; PCAST, 2010, 2012). In response to this need, there have been national calls to increase the number of engineers in the U.S. workforce (PCAST, 2012), and millions of taxpayers' dollars have been invested in education and research projects that respond to this call (Government Accountability Office, 2005). Moreover, the National Academy of Engineering (NAE) has led various efforts to understand and to improve the public's understanding of engineering (NAE, 2008a, 2013) - all in an attempt to increase young people's interests in pursuing engineering degrees. Although national interest is increasing, often times the emphasis of such conversations is on getting more students $t$ pursue undergraduate engineering degrees. Not as much national attention has been given to stimulating interests in graduate engineering degrees, in general, and engineering $\mathrm{PhDs}$, in particular.

Doctoral engineering education is a unique educational experience. It is set apart by coursework designed to facilitate the development of expertise in a niche area, research experiences that enable cutting-edge discoveries, and numerous opportunities to foster learning among undergraduate engineering students. Engineering $\mathrm{PhD}$ graduates go on to teach at universities, start businesses, and pursue rewarding careers in a variety of organizations. Engineering PhD holders who succeed in their careers possess keen abilities in conducting rigorous research, thinking analytically, communicating effectively, and working collaboratively (Austin, 2003; Cox et al., 2011; Watson \& Lyons, 2011b). The irony of the positive outcomes of doctoral engineering education and the disheartening statistics on U.S. engineering $\mathrm{PhD}$ graduates converge to create a niche research area worthy of further exploration.

There is a growing body of research on general doctoral education and engineering doctoral education. Many of the studies on general doctoral education relate to the shortcomings of current PhD programs (Nerad, Aanerud, \& Cerny, 2004; Nyquist \& Woodford, 2000), concerns surrounding doctoral education (e.g., lack of career preparation and mentoring, and an overemphasis on research) (Golde \& Dore, 2001; Nyquist \& Woodford, 2000), and recommendations for improving graduate education (Nerad \& Cerny, 2000; Nyquist, Woodford, \& Rogers, 2004). There have also been studies on persistence and attrition in doctoral education (Baker, Tancred, \& Whitesides, 2002; Mason, 2012; Spaulding \& Rockinson-Szapkiw, 2012; Tinto \& Clewell, 1997; Wao \& Onwuegbuzie, 2011). Within the context of doctoral engineering education, there have been studies on the career trajectories of engineering PhDs (Cox et al., 2013), competencies and skills $\mathrm{PhD}$ holders need for successful careers in industry and academia, and recommendations for improving doctoral engineering education in light of these career paths and desired attributes (Ahn, Cox, London, \& Zhu, 2013; Akay, 2008; Austin, 2003; Cox et al., 2011; Cox et al, 2012; Hoffman \& Nagl, 2011; Watson \& Lyons, 2011a, 2011b, 2012). While research on graduate education, persistence, attrition, skills, competencies and career trajectories of successful engineering $\mathrm{PhD}$ holders provides valuable insights for graduate engineering educators and aspiring PhD students, it is equally important to explore, beyond anecdotal observations, what motivates individu- 
als to start the journey to an engineering $\mathrm{PhD}$. To date, little is known about the entering phase of the PhD process (Brailsford, 2010; Gill \& Hoppe, 2009; Leonard, Becker, \& Coate, 2005).

Insights into factors influencing the decision to pursue a $\mathrm{PhD}$ are an important part of the doctoral engineering education research landscape. The topic of initial motivations has been explored in disciplines other than engineering, some of which include history (Brailsford, 2010), education (Leonard et al., 2005), and business (Gill \& Hoppe, 2009). One of the few studies specific to science and engineering is the National Science Foundation's (NSF) Survey of Earned Doctorates report (2012a), which includes factors that influence the path to a doctorate in science or engineering. Some efforts aim to increase the number of engineering PhD holders in the U.S. by targeting underrepresented minorities (URMs), and research on factors influencing this population's motivation, persistence, and career choices have been explored to this end (Donnelly, 2011; Ramirez, 2013; Simon, 2010). Other studies have explored returning engineering students' motivations to pursue graduate engineering studies (Peters \& Daly, 2013) and practicing engineers and engineering Master's students intentions to pursue doctoral engineering studies (Baytiyeh \& Naja, 2011a, 2011b). With the exception of the studies conducted by Donnelly (2011) and Simon (2010) on African American PhD holders, little research on motivations to pursue an engineering $\mathrm{PhD}$ in the U.S. are reported from the perspectives of the key stakeholders: engineering $\mathrm{PhD}$ holders in the U.S.

There is even less literature on what $\mathrm{PhD}$ recipients perceive as the added value of possessing a $\mathrm{PhD}$. One of the few studies on this topic was a reflective piece written by a government official in the U.K. (Lloyd-Williams, 2012). There are few empirical studies on the added value of having a $\mathrm{PhD}$, while there are more studies on what motivates people to get a $\mathrm{PhD}$. One reason for this may be because there is an assumption among researchers that what drives someone to get the degree is the same as the actual added value of possessing it. This study does not make this assumption and seeks to separate motivation from added value. It is not only important to understand what drives $\mathrm{PhD}$ holders to get the degree, but also their perspectives on ways in which the $\mathrm{PhD}$ adds value to their personal and professional lives post-graduation. Since both perspectives are valuable and missing from the literature, this study seeks to fills this gap.

In this study, 40 engineering PhD holders who earned their degrees in the U.S. participated in semi-structured interviews. Participants discussed what motivated them to pursue an engineering $\mathrm{PhD}$ along with the added value of possessing their degrees. The themes that emerged from the qualitative analysis will be discussed after the review of the existing literature surrounding this topic and after the explanation of methods for collecting and analyzing study data. An understanding of what motivates people to earn engineering $\mathrm{PhDs}$ and the perceived added value from the perspective of key stakeholders - engineering $\mathrm{PhD}$ holders - is a necessary perspective to include in the conversation on how to interest more people in earning engineering PhDs. Thus, the findings of this study have implications for educators developing graduate engineering curricula and policy makers interested in promoting initiatives that will motivate U.S. citizens to earn $\mathrm{PhDs}$ in engineering. Educators and policy makers around the world interested in doctoral engineering education will benefit from the findings of this study as well.

\section{Literature Review}

This section provides a summary of the literature on motivations for pursuing a $\mathrm{PhD}$ and the added value of possessing a $\mathrm{PhD}$.

\section{Motivation for Pursuing a PhD}

Little research has explored motivations for pursing doctoral training in engineering, however work in this area can be informed by research on motivations for pursuing doctoral training in 
other disciplines. Books that serve as guides for prospective $\mathrm{PhD}$ students sometimes include insights on reasons that people pursue PhDs (e.g., Churchill \& Sanders, 2007). However, such insights are usually not specific to a particular discipline. On the other hand, several researchers have examined motivations for pursuing doctoral training in the social sciences, education, business, and other science fields (Gill \& Hoppe, 2009; Leonard et al., 2005; Salmon, 1992). Within the context of engineering, there have been a few studies on engineers' intentions to pursue engineering $\mathrm{PhDs}$ and reasons for returning to graduate school after finishing a bachelor's degree in engineering and working for at least five years (Peters \& Daly, 2013). The studies most closely connected to the focus of this current research relate to factors that influenced African American $\mathrm{PhD}$ holders in the U.S. to pursue engineering PhDs (Donnelly, 2011; Simon, 2010). When looking across this collection of studies, five main motivations for pursuing a $\mathrm{PhD}$ emerge. The three biggest motivation factors relate to career development, interest in a topic or research, and personal motivations (e.g., Baytiyeh \& Naja, 2011b; Brailsford, 2010; Churchill \& Sanders, 2007). The two least common motivations for pursuing a $\mathrm{PhD}$ relate to prior experiences and the influence of an individual (e.g., Donnelly, 2011; NSF, 2012a). Each of these will be discussed in this review of the literature.

\section{Career development}

Motivations surrounding career development are among the primary factors for pursuing a $\mathrm{PhD}$. This factor fits within two of the five broad motivational categories identified by Churchill and Sanders (2007) in their Guide to Getting a PhD: A Practical Insider's Guide - career development and lack of current job satisfaction. For the study focused on what motivates business processionals to pursue a $\mathrm{PhD}$ (Gill \& Hoppe, 2009), motivational factors related to career development accounted for four out of five of the factors that were cited in the research findings. The participants in this study pursued their $\mathrm{PhD}$ with the objectives for pursuit of an academic career, for professional development, for professional advancement, or for entry into a new career. But this motivation is not unique to business professionals. Some history $\mathrm{PhD}$ holders pursued the degree because of "employment and career considerations" (Brailsford, 2010), while some education $\mathrm{PhD}$ holders talked about this motivation as a vocational requirement (Leonard et al., 2005).

Career development is a motivational factor for engineers as well. In fact, students returning to graduate studies after earning a bachelor's in engineering and working for at least five years mentioned the advantages of graduate engineering degrees furthering their career goals (Peters \& Daly, 2013). On the contrary, only one engineering PhD participant in the study conducted by Simon (2010) mentioned job promotion as a primary motivating factor. (The authors noted that this participant had more job experience that most of the participants in the study and that this may have had an influence on their perspective.)

\section{Research interest}

Interest in a topic or research is another major factor that motivates people to earn a $\mathrm{PhD}$ in various disciplines. This factor was mentioned by $\mathrm{PhD}$ holders in almost all of the disciplines included in the review of the literature - namely, social scientists (Salmon, 1992), historians (Brailsford, 2010), educators (Leonard et al., 2005), and engineers (Baytiyeh \& Naja, 2011a, 2011b). This motivational factor includes the desire to acquire research skills and/or affect change in relation to a particular concern or some aspect of our everyday lives. Churchill and Sanders (2007) categorized the latter of these two desires as "personal agenda" (p. 15) and "research as politics" (p. 16). Engineers who cited this factor mentioned interests in making new things, conducting research, and learning more about the study of engineering (Baytiyeh \& Naja, 2011a, 2011b). 


\section{Personal factors}

The third of the largest three motivations for earning a $\mathrm{PhD}$ pertain to personal motivational factors. Social scientists talked about it as a sense of identity (Salmon, 1992), while some business professionals pursued a $\mathrm{PhD}$ for the objective of self-enrichment (with little or no extrinsic motivating factors) (Gill \& Hoppe, 2009). For the education PhD holders, personal development and general intellectual interest outweighed their vocational concerns (Leonard et al., 2005). As the title of the researchers' article indicates, "To Prove Myself at the Highest Level", participants in this study talked about earning the $\mathrm{PhD}$ as a way of proving themselves. Engineers who have participated in studies surrounding this topic said they always knew they would get an advanced degree (Donnelly, 2011), and one participant mentioned that it was a decision she made on their own with little to no influence from others (Simon, 2010).

\section{Prior experience, influence of others}

Two motivational factors that show up the least often in the literature on what motivates people to earn a PhD are prior experiences and the influence of someone. Churchill and Sanders (2007), in their Guide to Getting a PhD, identify a motivation category called "drifting in," that relates to the idea of prior experiences. This label is intended to describe the instances where the pursuit of a $\mathrm{PhD}$ is a less conscious choice; it is simply the natural progression of events after undergraduate and graduate studies. Within the context of engineering, on the other hand, prior experiences include exposure to research (Donnelly, 2011; Simon, 2010) or participation in an internship (Simon, 2010).

As it relates to motivations stemming from the influence of someone, history $\mathrm{PhD}$ holders listed the influence of family, friends, colleagues, and academics. Engineers who cited this motivation, however, talked about someone encouraging them to pursue the degree, but did not necessarily name categories of individuals. According to NSF's recent Survey of Earned Doctorates report (NSF, 2012a), the highest educational attainment of the parents of the perspective PhD students seemed to influence their paths to the doctorate in science and engineering. Surprisingly, in a study including Lebanese practicing engineers and engineering Master's students' intentions to pursue an engineering $\mathrm{PhD}$, parents with a $\mathrm{PhD}$ "seem to not have any influence on the interest/lack of interest of participants in pursuing [a] PhD degree" (Baytiyeh \& Naja, 2011b, p. 4). This is also worth mentioning in light of the factors that influence the path to the doctorate according to the results of NSF's survey (2012a). Thus, the influence of parents on getting an engineering $\mathrm{PhD}$ seems to be inconsistent in the few studies on this topic and is an area worthy of further study.

\section{Other motivational factors}

Lastly, there are two motivational factors mentioned in the literature that seem anecdotal at this point but should be included because of the exploratory nature of this study and the desire to connect the findings of this study with the current literature. Education PhD holders talked about being motivated by the desire to acquire the name degree, since there is such prestige associated with the $\mathrm{PhD}$ (Leonard et al., 2005). Secondly, institutions influence science and engineering students' path to the doctorate degree (NSF, 2012a). More specifically, institutions classified as "very high research activity," according to the Carnegie Foundation's classification of institutions of higher education, award most of the doctoral degrees in the US. This means that the number of engineering PhD graduates in the U.S. may be proportionate to the number institutions with "high research activity"; by extension, an increase in one might lead to an increase in the other.

While there are more studies on the motivations for getting a $\mathrm{PhD}$ in fields other than engineering, the current literature on this topic does reveal some important patterns. More often than not, $\mathrm{PhD}$ holders mention motivations related to future careers and professional development, interest 
in a topic and/or research and personal motives. Prior experiences and the influence of someone is mentioned the least often by PhD holders outside of engineering, but was commonly cited among the few studies including engineers a participants. Two other motivating factors are interesting, but are only mentioned in two studies (Leonard et al., 2005; NSF, 2012a). The study presented here includes the perspectives of not just those interested in pursuing an engineering $\mathrm{PhD}$, but those who actually earned one. Moreover, it would also be interesting to hear not only the motivations for getting the degree, but also what engineering $\mathrm{PhD}$ recipients talk about as the added value of possessing it.

\section{Added Value of Earning a PhD}

While there are few studies on what motivates people to earn a $\mathrm{PhD}$, there are even fewer studies on what $\mathrm{PhD}$ recipients perceive as the added value of holding the degree. One study on this topic was a reflective piece written by a PhD holder and U.K. government official who works in the area of governance, legality, and probity (Lloyd-Williams, 2012). At the most fundamental level, earning a $\mathrm{PhD}$ brings a new set of skills and understanding. On a more reflective note, the $\mathrm{PhD}$ changed how he saw himself, enabled new ways of thinking, and gave him a new perspective on life and a broader worldview. The following statement speaks to ways the author's thinking changed: "The act of reflecting on and contemplating the opinions of academics afforded me space to think about my own perspectives and responses ... I became much more aware of my own influence on situations, conversations, and decisions" (Lloyd-Williams, 2012, pp. 56-57). When sharing reflections on how the cost of $\mathrm{PhD}$ can be justified in terms of its commercial value, he talks about "how [his] advice to the corporation is richer in its connectivity with praxis, grounded in direct experience and learning from others and likely to reduce corporate risks, as more thought has been given to how the advice I give is used in practice" (Lloyd-Williams, 2012, p. 57). Lastly, he commented on his role as a manager and the richness of the contribution a $\mathrm{PhD}$ holder adds to his department. More specifically, he highlights their ability "to think strategically and long term; [and] apply a critical approach to problem solving and innovation to researching work-place problems" (Lloyd-Williams, 2012, p. 58). In sum, this article talks about the added value of a PhD in terms of additional skills and insights, new ways of thinking, better-informed responses to inquiries related to their area of expertise, and the unique assets a $\mathrm{PhD}$ holder brings to a group in a work environment. Though insightful, this is only one $\mathrm{PhD}$ holder's perspective the value of $\mathrm{PhD}$. As such, it would be valuable to add other $\mathrm{PhD}$ holders' perspectives on this discussion.

The purpose of this study is to describe the motivations and added value of earning an engineering $\mathrm{PhD}$. The research questions guiding this study are:

1. What motivated engineering $\mathrm{PhD}$ professionals to earn an engineering $\mathrm{PhD}$ ?

2. What is the added value of earning an engineering $\mathrm{PhD}$ ?

\section{Research Methods}

\section{Data Collection}

The data for this study are from a larger data set collected for a NSF-funded project focused upon the preparation of doctoral students for careers in academia and industry. Unlike most studies that focus on the preparation of graduate students for academic careers, the project team wanted to explore the experiences of engineering $\mathrm{PhD}$ graduates in industry, the occupational sector where most engineering PhD holders are employed (NSF, 2012b). As a result of this, researchers conducted one-on-one semi-structured interviews with 40 engineering $\mathrm{PhD}$ holders working in industry and academia. A 16-item interview protocol was used to examine their perceptions of knowl- 
edge, skills, attributes, and work-related expectations of engineering $\mathrm{PhD}$ holders; their doctoral experiences and recommendations for doctoral engineering programs; and their motivations and perceived added value of earning an engineering $\mathrm{PhD}$. The specific interview questions of interest in this study are: How did you decide to earn an engineering PhD? and Based on your experience, is there any added value of getting a PhD in engineering as opposed to only a Bachelor's or Master's degree? Participants' responses to these two protocol questions were analyzed in this study.

\section{Participants}

Participants included 40 engineering PhD holders with five to twenty-five years of work experience after earning their doctorate. All participants were classified according to the employment sector in which they worked since the receipt of a PhD: (1) academia only (AC), (2) industry only (IN), (3) industry first and then academia (IN-AC), and (4) academia first and then industry (ACIN). Throughout the rest of this document, these four sectors will be referred to as AC, IN, IN$\mathrm{AC}$, and AC-IN, respectively. Tables 1-4 summarize the demographic information about the participants.

Table 1: Demographics of participants who have only worked in academia post-PhD (AC)

\begin{tabular}{|c|c|c|c|c|}
\hline \# Years & Gender & Status & Field & Current Position \\
\hline \multirow{4}{*}{$\begin{array}{c}\text { Less than } 5 \\
\text { Years }\end{array}$} & $\mathrm{F}$ & Domestic & $\mathrm{ME}$ & Assistant Professor \\
\hline & $\mathrm{M}$ & Domestic & ECE & Assistant Professor \\
\hline & $\mathrm{F}$ & Domestic & ChemE & Lecturer \\
\hline & $\mathrm{M}$ & Domestic & $\mathrm{AE}$ & Assistant Professor \\
\hline \multirow{6}{*}{ 5-10 Years } & $\mathrm{M}$ & International & $M E \& A E$ & Assistant Professor \\
\hline & $M$ & Domestic & ME & Research Associate, Lecturer \\
\hline & $\mathrm{F}$ & Domestic & $\mathrm{EE}$ & Assistant Professor \\
\hline & $\mathrm{F}$ & Domestic & ECE & Assistant Professor \\
\hline & $\mathrm{F}$ & International & MSE & Assistant Professor \\
\hline & $M$ & Domestic & ChemE & Profressor \\
\hline \multirow{5}{*}{$\begin{array}{l}10-20 \\
\text { Years }\end{array}$} & $\bar{F}$ & Domestic & $\mathrm{ME}$ & Lecturer; Outreach Director \\
\hline & $\mathrm{M}$ & Domestic & $\mathrm{ME}$ & Profressor \\
\hline & $\mathrm{M}$ & Domestic & $\mathrm{EE}$ & V.P. of Higher Education Policy \\
\hline & $M$ & Domestic & BME & Adjuct Assistant Professor \\
\hline & $\bar{F}$ & Domestic & ChemE & Associate Professor \\
\hline \multirow{2}{*}{$\begin{array}{c}\text { More than } \\
20 \text { Years }\end{array}$} & $\mathrm{M}$ & Domestic & ECE & Professor \& Department Chair \\
\hline & $M$ & Domestic & Aero & Professor \\
\hline
\end{tabular}


Table 2: Demographics of participants who have only worked in industry post-PhD (IN)

\begin{tabular}{|c|c|c|c|c|}
\hline \# Years & Gender & Status & Field & Current Position \\
\hline \multirow{4}{*}{$\begin{array}{c}\text { Less than } \mathbf{5} \\
\text { Years }\end{array}$} & $\mathrm{M}$ & International & ChemE & Mechanical Engineer \\
\cline { 2 - 5 } & $\mathrm{M}$ & Domestic & $\mathrm{ECE}$ & Software Engineer \\
\cline { 2 - 5 } & $\mathrm{M}$ & Domestic & $\mathrm{IE}$ & Professional Training Director \\
\cline { 2 - 5 } & $\mathrm{F}$ & Domestic & $\mathrm{BME}$ & Systems Design Engineer \\
\hline \multirow{2}{*}{$\mathbf{5 - 1 0}$ Years } & $\mathrm{M}$ & Domestic & ChemE & Scientist \\
\cline { 2 - 5 } & $\mathrm{F}$ & Domestic & ChemE & Engineering Associate \\
\hline $\mathbf{1 0 - 2 0}$ & $\mathrm{M}$ & Domestic & $\mathrm{IE}$ & Senior Manager \\
\hline \multirow{3}{*}{$\begin{array}{c}\text { More than } \\
\text { 20 Years }\end{array}$} & $\mathrm{M}$ & Domestic & ChemE & $\begin{array}{c}\text { Director, Research and } \\
\text { Development }\end{array}$ \\
\cline { 2 - 5 } & $\mathrm{M}$ & Domestic & ChemE & Director, Process Engineering \\
\hline
\end{tabular}

Table 3: Demographics of participants who worked in industry then academia post-PhD (IN-AC)

\begin{tabular}{|c|c|c|c|c|}
\hline \# Years & Gender & Status & Field & Current Position \\
\hline 5-10 Years & $\mathrm{M}$ & Domestic & ChemE & Postdoctoral Fellow \\
\hline \multirow{3}{*}{$\begin{array}{c}\mathbf{1 0 - 2 0} \\
\text { Years }\end{array}$} & $\mathrm{F}$ & Domestic & ECE & Assistant Professor \\
\cline { 2 - 5 } & $\mathrm{M}$ & Domestic & ChemE & Department Chair \\
\cline { 2 - 5 } & $\mathrm{M}$ & Domestic & $\mathrm{MSE}$ & Associate Department Chair \\
\cline { 2 - 5 } & $\mathrm{M}$ & Domestic & ChemE & Professor \\
\hline \multirow{3}{*}{$\begin{array}{c}\text { More than } \\
\text { 20 Years }\end{array}$} & $\mathrm{M}$ & Domestic & $\mathrm{ECE}$ & Distinguished Professor \\
\cline { 2 - 5 } & $\mathrm{M}$ & Domestic & ChemE & Founder, Senior Lecturer \\
\cline { 2 - 5 } & $\mathrm{M}$ & Domestic & $\mathrm{EE}$ & Professor \\
\cline { 2 - 5 } & $\mathrm{M}$ & Domestic & ChemE & Lecturer \\
\hline
\end{tabular}

Table 4: Demographics of participants who worked in academia then industry post-PhD (AC-IN)

\begin{tabular}{|c|c|c|c|c|}
\hline \# Years & Gender & Status & Field & Current Position \\
\hline \multirow{3}{*}{$\begin{array}{c}10-20 \\
\text { Years }\end{array}$} & $\mathrm{M}$ & International & $\mathrm{EE}$ & Chief Technology Officer \\
\cline { 2 - 5 } & $\mathrm{M}$ & International & $\mathrm{EE}$ & Director \\
\cline { 2 - 5 } & $\mathrm{M}$ & Domestic & $\mathrm{ME}$ & Principal Engineer \\
\cline { 2 - 5 } & $\mathrm{M}$ & Domestic & $\mathrm{ME}$ & Engineering Technical Steward \\
\hline
\end{tabular}

Basic demographics include: gender (twenty-nine males and eleven females), years of experience (nine with less than 5 years of experience, nine with 5-10 years of experience, fourteen with 1020 years of experience, and eight with more than 20 years of experience), occupational sector (seventeen AC, ten IN, four AC-IN, and nine IN-AC), the participant's position (according to the curriculum vitae they provided) at the time of the interview, and the engineering field in which they earned their $\mathrm{PhD}$. The seven engineering disciplines of the participants in this study include: aerospace engineering (AE), biomedical engineering (BME), chemical engineering (ChemE), electrical and/or computer engineering (ECE or EE), industrial engineering (IE), materials science and engineering (MSE), and mechanical engineering (ME). The participants were asked at 
the end of the interview whether they identified themselves as a domestic or international student when pursuing their engineering $\mathrm{PhD}$ in the U.S.; 34 self-identified as "domestic" students, while 6 self-identified as an "international" student.

\section{Data Analysis}

Members of the research team conducted all 40 interviews. The interviews were recorded and later transcribed by an external transcriber. Members of the research team used Atlas.ti, a software program used in qualitative research, to analyze the transcripts. An open coding and constant comparative method (Glaser \& Strauss, 1967) were used to study the views of the respondents. In the first phase of data analysis, two transcripts were selected randomly, and each researcher assigned a descriptive word (or code) next to a segment(s) of text that best matched the essence of the response. This process involved reading the data multiple times and making memos about phrases and ideas that stood out. All members individually identified and recorded the codes using the software. During research meetings, the team engaged in an auditing process where the team members discussed the appropriateness of the code assigned to segments of the participants' responses. Codes that were agreed upon among all researchers were recorded in a separate document, which later became the foundation for the codebook for the study. The codes were organized into 11 categories. The two categories most relevant in this study are "Motivation" and "Added Value". The research team members were assigned two additional randomly selected transcripts to analyze. This led to more discussion and the addition of new codes and/or refinement of existing codes in the codebook (e.g., clarifying existing code definitions and coding rules, including code examples, and indicating when and when not to use a code). The remaining 36 transcripts were randomly assigned to members of the research team, and team members were asked to code the transcripts using the existing codebook and add codes if necessary. After this coding process was complete, all codes were compiled into one codebook. In preparation for the final round of auditing meetings, team members reviewed all of the codes in the codebook to identify redundant codes and to propose definitions and examples of remaining codes. The team members discussed the final codes in the codebook over a series of meetings. In the final version of the codebook, 301 codes are organized into 11 categories. There were 14 "Motivation" codes, and 29 "Added Value" codes.

After the inter-rater reliability tests were complete (see details in the next section), the coding workload was divided by a set of protocol questions rather than by whole transcripts in order to minimize the number of codes with which a single coder needed to be familiar. For example, one researcher was responsible for coding all 40 participants' responses to interview questions related to the participants" motivations for pursuing an engineering $\mathrm{PhD}$. This form of "question-based coding" is consistent with a structural coding strategy (Saldana, 2013, p. 84). This coding approach enabled more efficiency, greater accuracy, and a more reasonable mental workload.

The focus of this study is on the analysis of participants' responses to two protocol questions: How did you decide to earn an engineering PhD? and Based on your experience, is there any added value of getting a PhD in engineering as opposed to only a Bachelor's or Master's degree? As the structural coding approach suggests (Saldana, 2013), the researcher responsible for coding responses to the first question used the "Motivation" codes in the codebook to assign codes to segments of the participants' responses describing their motivations for earning a $\mathrm{PhD}$. In the event that there was a need to create a new "Motivation" code, the researcher assigned the new descriptive word (or code) to the segment, and added it to the final version of the codebook. After all of the responses were coded, the researcher used SPSS software to generate tables summarizing the "Motivation" codes and their frequency counts (see Table 5 in the results section).

In addition to looking at the frequency of responses, researchers identified the major motivational themes. To generate themes for the data, the researchers followed the "Qualitative Process of 
Data Analysis" as described by Creswell (2008, p. 41). This includes iteratively reading through the participants' quotes and the assigned codes several times to understand connections between the data and the codes, to form clusters of related codes, and to identify the major ideas represented in data. The major ideas that resulted from this stage of the analysis are the four themes presented in the results section of this paper. The same process was repeated for responses to the protocol question related to "Added Value". The results presented in this paper will include the results of the analysis on the frequency of codes and themes that emerged from responses to the protocol questions.

\section{Inter-rater Reliability}

In the second phase of the data analysis, two inter-rater reliability (IRR) tests were conducted once the codebook was finalized and before coders began coding transcripts independently. IRR test ensures that researchers independently agree on the data sections to be coded and codes to be assigned (Creswell, 2008, p.41). One measure of IRR is percent agreement. Percent agreement is a measure of the overall consistency between the codes an individual researcher assigns to a segment of text, and the code assignment agreed upon by the research team during the auditing process. To conduct the IRR analysis in this study, four transcripts were randomly selected. The only restriction on this selection was that the four employment classifications of interest in the larger study (AC, IN, IN-AC, and AC-IN) needed to be represented among the four transcripts for the IRR analysis. In an attempt to include perspectives from participants across all four sectors while assessing inter-rater reliability, responses to the 16 interview questions were randomly selected from the four transcripts and combined to form a "mixed-transcript". The researchers used the final version of the codebook to code individually the mixed transcript. This process involved researchers selecting the code that best represented the quotes.

The first round of IRR analysis resulted in $75 \%$ overall agreement for the responses to the 16 questions. Percent agreement was calculated on an individual basis as well as overall. From an individual perspective, percent agreement was based on the extent to which the codes researchers assigned to responses matched the codes that were determined during the auditing process. Each coder's overall percent agreement was also calculated. The $75 \%$ overall agreement is an average of the individual percent agreement values. Although fair coding agreement existed among the researchers, there were three protocol questions where all of the coders had a low (less than 75\%) percent agreement. The low percent agreement occurred when there were multiple ideas in a sentence or a paragraph and researchers did not assign all of the codes reflected in the response. Therefore, the research team conducted another round of IRR for just these three questions. A different mixed-transcript was generated and used to minimize bias. The IRR for the three questions resulted in overall percent agreement of $79 \%$.

Since percent agreement includes agreements that happen by chance or guessing, a second IRR measure was used in this study, Fleiss' kappa (Gwet, 2010), which can be used to assess the IRR between two or more raters when assigning categorical ratings to a fixed number of items. In this case, four raters used the 301 codes in the final version of the codebook to assigned codes to a new mixed transcript. The $\kappa$-value was 0.61. According to Fleiss (1971), this value can be interpreted as "substantial agreement". Given a good rating agreement among all coders for all interview questions, each researcher was assigned a set of interview questions and coded all participants' responses to their assigned set of questions. The findings of this study will be presented in the next section. This will include insights on the motivation for and added value of earning an engineering $\mathrm{PhD}$. 


\section{Results}

This section is organized into two main sections. The first section focuses on the motivations for earning an engineering $\mathrm{PhD}$. The second section focuses on the added value of earning an engineering $\mathrm{PhD}$. Both sections will begin with the codes that were mentioned the most frequently among the participants across employment sectors. Since there were fewer participants who transitioned between sectors than those who have only worked in only one sector, the results of the participants in AC-IN and IN-AC were combined in order to see patterns across participants. The most frequent codes will be followed by a synthesis of how all of the codes cluster into larger themes.

\section{Motivations for Earning an Engineering PhD across Sectors}

This section describes participants' responses to the following question: How did you decide to earn an engineering PhD? Participants were encouraged to share what motivated them to get the degree or what kept them motivated throughout the experiences. Some participants shared what should motivate others who are thinking about getting an engineering $\mathrm{PhD}$.

Various insights emerge from looking at motivations for pursuing an engineering $\mathrm{PhD}$ across the four employment sectors. Table 5 summarizes the top three motivation codes mentioned by the participants in each sector. The number of times the response was mentioned is included in parentheses next to the code. For the instances where there were an equal number of responses for a code, all codes are listed and associated with the same rank. Most participants cited more than one factor that influenced their decision to earn a $\mathrm{PhD}$. (This is why the sum of the numbers in parentheses next to each code in a sector may exceed the number of participants in a sector). Also included is a column labeled "Across All Sectors," which represents the top three responses irrespective of the employment sector (AC, IN, AC-IN, and IN-AC). Only the top three most frequent "Motivation" codes are included in the frequency table. Other motivations (besides those included in the top three) were not included in this table because so few participants in a sector cited it that it was not considered representative of a primary motivational factor for participants in that sector.

Table 5: Motivations for Earning an Engineering PhD across Sectors

\begin{tabular}{|c|c|c|c|c|}
\hline \multicolumn{5}{|c|}{ Motivation - Top 3 Most Frequent Codes } \\
\hline Rank & $A C(n=17)$ & IN $(n=10)$ & IN-AC \& AC-IN (n=13) & Across All Sectors ( $n=40$ ) \\
\hline 1 & $\begin{array}{l}\text { Opportunity to go into an } \\
\text { academic profession ( } n=12)\end{array}$ & \begin{tabular}{|l|} 
Passionate about the technical \\
subject/topic of interest $(n=8)$
\end{tabular} & Personal interest $(n=8)$ & $\begin{array}{l}\text { Influenced by mentors, } \\
\text { teachers, professors }(n=21)\end{array}$ \\
\hline \multirow{3}{*}{2} & Personal interest $(n=8)$ & \multirow{3}{*}{$\begin{array}{l}\text { Passionate about research } \\
(n=4)\end{array}$} & \multirow[b]{2}{*}{$\begin{array}{l}\text { Passionate about the technical } \\
\text { subject/topic of interest }(n=5)\end{array}$} & \multirow[b]{2}{*}{$\begin{array}{l}\text { Passionate about the technical } \\
\text { subject/topic of interest }(n=18)\end{array}$} \\
\hline & $\begin{array}{l}\text { Passionate about something } \\
\text { associted with your technical } \\
\text { subject, but not research }(n=8)\end{array}$ & & & \\
\hline & \begin{tabular}{|l|} 
Influenced by mentors, \\
teachers, professors $(n=8)$ \\
Have a goal that necessitates a \\
PhD $(n=8)$
\end{tabular} & & $\begin{array}{l}\text { Influenced by mentors, } \\
\text { teachers, professor }(n=5)\end{array}$ & $\begin{array}{l}\text { Opportunity to go into an } \\
\text { academic profession }(n=18)\end{array}$ \\
\hline \multirow{3}{*}{3} & \multirow{3}{*}{$\begin{array}{l}\text { Passionate about research } \\
(\mathrm{n}=6)\end{array}$} & $\begin{array}{l}\text { Opportunity to go into an } \\
\text { academic profession ( } n=3)\end{array}$ & $\begin{array}{l}\text { Prior success in graduate } \\
\text { school }(n=4)\end{array}$ & \multirow{3}{*}{ Personal interest $(n=17)$} \\
\hline & & \multirow{2}{*}{$\begin{array}{l}\text { Influenced by a family member } \\
(n=3)\end{array}$} & $\begin{array}{l}\text { Have a goal that necessitates a } \\
\operatorname{PhD}(n=4)\end{array}$ & \\
\hline & & & $\begin{array}{l}\text { Passionate about research } \\
(n=4)\end{array}$ & \\
\hline
\end{tabular}

*() numbers in parentheses indicates the number of participants in each sector who mentioned this code 
There are some motivating factors that are unique to a sector while others recur across sectors. For participants who have only worked in academia, the most frequently mentioned motivation for pursuing an engineering $\mathrm{PhD}$ was the opportunity to go into an academic profession. On the other hand, IN participants most often reported their passions for a technical subject and the influence of mentors, teachers, and professors as primary motivators. Additionally, IN participants noted the influence of a family member among the top motivating factors for earning a $\mathrm{PhD}$. This is the only sector in which this code shows up among the top three motivators. For AC-IN and IN-AC participants, personal interest was the primary motivation for their pursuit of an engineering $\mathrm{PhD}$. This code is intended to capture participants' longstanding desire to earn a PhD in the absence of other apparent motivators. Statements like, "Earning a PhD was something I have always wanted to do" is an example of a participant's personal interest. Lastly, this is the only sector where "prior success in graduate school" (e.g., successfully completing a Master's degree) was among the top three motivating factors that influenced the participants to get an engineering $\mathrm{PhD}$.

When looking across all four sectors, the "influence of mentors, teachers and professors" is the biggest motivating factor for pursuing an engineering $\mathrm{PhD}$. Unlike all of the other codes in the "Across All Sectors" column, it is the only motivating factor that is listed among the top three codes independent of the sector. Overall, an equal number of participants (18) mentioned that they pursued an engineering $\mathrm{PhD}$ because they were "passionate about the technical subject/topic of interest" and/or the "opportunity to go into an academic profession". Both of these motivating factors, along with "personal interest", are among the top three motivating factors for two of the other employment sectors (i.e., AC and IN-AC \& AC-IN). Lastly, "passionate about research" is listed among the top three motivations for each of the individual sectors (often times in the third rank), it was not mentioned frequently enough to be a top motivation irrespective of the sector; this is why it is not listed in the "across all sectors" column. The next section presents themes that emerged across all (14) motivation codes. The themes were determined based upon an analysis of relationships between all of the "Motivation" codes. The themes emerged as a result of labeling the clusters of related codes.

\section{Motivations for Earning PhDs in Engineering}

Participants were asked to share what motivated them to earn an engineering $\mathrm{PhD}$ or what kept them motivated throughout their engineering doctoral experiences. Researchers found that both internal and external factors influence someone's decision to pursue an engineering $\mathrm{PhD}$. The motivations for earning an engineering $\mathrm{PhD}$ regardless of employment sector can be organized into four major themes: (1) Engineering PhD Needed for Career Aspirations; (2) Graduate School-Related Motivations; (3) Influenced to Obtain a PhD; and (4) Intrinsic Motivational Factors. Participants in this study described their motivations in terms of one of these four major themes, and some participants had multiple motivations that included more than one of the four major themes.

\section{Engineering PhD Needed for Career Aspirations}

The motivation to earn an engineering $\mathrm{PhD}$ because of career aspirations manifests itself in different ways. It may stem from discontentment with a current role, an interpretation of market trends that suggest that an advanced degree is critical to remaining competitive in a changing workforce, or a lack of opportunities upon completion of a Master's degree in engineering. Opportunities that await many $\mathrm{PhDs}$ are another way to describe this motivation - namely, opportunities to conduct scientific research, go into an academic profession, or to pursue a career track in industry/business. In most cases, these career opportunities are perceived as necessitating an en- 
gineering $\mathrm{PhD}$. More often than not, participants described roles in the academy, not in industry, as having this requirement.

An engineering professor commenting on her desire to do scientific work in her future role said it this way: "I definitely wanted to have more control over scientific problems and work at a level that you couldn't do with a bachelor's degree."

One mechanical engineer working in industry shared:

So my observation at that point in time was that people in industry to advance had Master's degrees. And the trend I saw was that the Master's degree was becoming more common so a PhD would give me additional power, a type of advantage.

\section{Graduate School-Related Motivations}

While some participants were motivated by career aspirations, others were motivated by factors related to graduate school. This might include being exposed to graduate education opportunities (via workshops, social events, research, etc.) or from prior success in graduate studies. Receiving funding to attend graduate school is another way in which this motivation is revealed.

Participants working in both academia and industry talked about "passing qualifying exams" and "securing fellowship funding for a $\mathrm{PhD}$ " when describing graduate school as part of their motivating factor. Passing qualifying exams can be a motivating factor because it can provide affirmation of developing expertise and add to the confidence that you have what it takes to complete doctoral studies. Securing a fellowship, on the other hand, can be motivating because it minimizes inhibitors associated with finances.

\section{Influenced to Obtain a PhD}

The first two of the four major motivation themes (i.e. Engineering PhD Needed for Career Aspirations and Graduate School-Related Motivations) relate to professional goals and graduate school. The third relates to the being influenced to obtain an engineering $\mathrm{PhD}$. More specifically, participants talked about the influence of a family member, teacher, mentor (including peer mentors), and/or professors. This influence may have been in the form of encouraging words or by the examples of a $\mathrm{PhD}$ who interacted with the participant on a regular basis.

One engineering professor explained:

So my father was a professor. And I knew what the lifestyle was like of a faculty member at a university. He taught psychology. But I, you know, grew up around universities and I liked them, so I always had positive experiences on campus.

A chemical engineer working at a Fortune 500 company still remembers her advisor's words:

My thesis advisor... was very influential in saying, 'You have this state, they have the money available, just continue to go on. Don't be too concerned about working, you know, rushing to work, just, you know, continue to go forward since you have your support network here and you have the capability.'

\section{Intrinsic Motivational Factors}

There are times in which intrinsic factors affected the participants' decision to pursue an engineering $\mathrm{PhD}$. For example, there are many who pursue the degree because of a passion to conduct research or passion for a particular technical subject or topic. Others choose to pursue the degree because of personal interest or a longstanding desire to hold a $\mathrm{PhD}$. This motivation also includes the pursuit of the degree because of a desire to differentiate themselves from others in their field (e.g., possessing an unique skillset or pursuing an atypical line of work). 
One professor mentioned having an interest in the pursuit of an engineering $\mathrm{PhD}$ as early as high school. Another professor was emphatic about what he perceived as the appropriate purpose for pursuing the degree; he said, "If your purpose is to attain a higher qualification, I think it's a waste of time because the PhD is not about the qualification. It's about the passion to study your subject."

An engineering manager working at in the medical devices industry mentioned "always" having an interest in "studying problems to the depth". One participant who has worked in both industry and academia talked about pursuing an engineering $\mathrm{PhD}$ because he "wanted to be challenged."

\section{Added Value of Earning an Engineering PhD Across Employment Sectors}

In addition to questions about their motivations for pursuing a $\mathrm{PhD}$, participants were asked to respond to the following question: Based on your experience, is there any added value of getting a PhD in engineering as opposed to only a Bachelor's or Master's degree? Many insights emerge from looking across employment sectors at the added value of earning an engineering $\mathrm{PhD}$. Participants noted additional knowledge, skills, and attributes gained by receiving an engineering PhD and discussed perspectives about opportunities that engineering PhDs offer. Table 6 summarizes the top three added value codes mentioned by the participants in each sector. As in Table 5, the number of times the response was mentioned is included in parentheses next to the individual codes. For the instances where there were an equal number of responses for a code, all codes are listed and associated with the same rank. Also included is a column labeled "across all sectors," which includes the most frequently occurring codes across all participants.

Table 6: Added Value of Earning an Engineering PhD across Sectors

\begin{tabular}{|c|c|c|c|c|}
\hline \multicolumn{5}{|c|}{ Added Value - Top 3 Most Frequent Codes } \\
\hline Rank & $A C(n=17)$ & IN $(n=10)$ & IN-AC \& AC-IN (n=13) & Across All Sectors $(n=40)$ \\
\hline \multirow{2}{*}{1} & $\begin{array}{l}\text { Requirement for academic } \\
\text { profession }(n=13)\end{array}$ & \multirow{2}{*}{$\begin{array}{l}\text { Access to more opportunities } \\
(n=6)\end{array}$} & \multirow{2}{*}{$\begin{array}{l}\text { Deeper understanding of } \\
\text { fundamental concepts }(n=8)\end{array}$} & \multirow{2}{*}{$\begin{array}{l}\text { Ability to do scientific work } \\
(n=24)\end{array}$} \\
\hline & $\begin{array}{l}\text { Ability to do scientific work } \\
(n=13)\end{array}$ & & & \\
\hline \multirow{3}{*}{2} & \multirow{3}{*}{$\begin{array}{l}\text { Added value depends on career } \\
\text { goal }(n=10)\end{array}$} & $\begin{array}{l}\text { Limitations of getting a PhD } \\
(n=5)\end{array}$ & $\begin{array}{l}\text { Ability to do scientific work } \\
(n=6)\end{array}$ & \multirow{3}{*}{$\begin{array}{l}\text { Deeper understanding of } \\
\text { fundamental concepts }(n=17)\end{array}$} \\
\hline & & Builds confidence $(n=5)$ & \multirow{2}{*}{$\begin{array}{l}\text { Access to more opportunities } \\
(\mathrm{n}=6)\end{array}$} & \\
\hline & & $\begin{array}{l}\text { Ability to do scientific work or } \\
\text { research }(n=5)\end{array}$ & & \\
\hline \multirow{2}{*}{3} & \multirow{2}{*}{$\begin{array}{l}\text { Flexibility in designing your } \\
\text { career }(n=8)\end{array}$} & \multirow{2}{*}{ Fiscal benefits $(n=3)$} & $\begin{array}{l}\text { Requirement for a profession } \\
(n=5)\end{array}$ & \multirow{2}{*}{$\begin{array}{l}\text { Access to more opportunities } \\
(n=16)\end{array}$} \\
\hline & & & $\begin{array}{l}\text { Flexibility in designing your } \\
\text { career }(n=5)\end{array}$ & \\
\hline
\end{tabular}

*() numbers in parenthesis indicates the number of participants in each sector who mentioned this quote

There are some added value codes that are unique to an employment sector. For example, the added value for earning an engineering $\mathrm{PhD}$ associated with the "requirement for a profession" only shows up in sectors that include academia (i.e., AC, IN-AC, and AC-IN). Additionally, participants who have only worked in academia highlighted that the "added value depends on career goals" more often than participants in any other sector. On the other hand, "flexibility in designing your career" is listed in every sector except industry. Participants who are currently working in industry mentioned the "fiscal benefits" of earning an engineering $\mathrm{PhD}$ and the "limitations" of possessing it most often. 
When looking across all four sectors, the "ability to do scientific work" is the added value that is most often cited by engineering PhD holders. This added value is present in the top three codes across all employment sectors. This may include, but is not limited to, identifying a research problem, determining a systematic way to address the problem, and using technology and techniques appropriately as part of collecting and analyzing data. "Deeper understanding of fundamental concepts" is the second among the top three most frequently mentioned added values. This factor is repeated among the top three codes for participants who have transitioned between academia and industry but does not show up in the top three codes for those who worked in academia only or industry only. "Access to more opportunities" is also among the top three when looking across all four sectors. As it relates to the individual sectors, this code shows up in every sector except academia only. The next section will include themes that emerged across all (29) added value codes. The themes were determined based upon an analysis of relationships between all of the "Added Value" codes, and the themes emerged as a result of labeling the clusters of related codes.

\section{Added Value of Earning an Engineering PhD}

Participants were asked to identify the added value of earning an engineering $\mathrm{PhD}$ over a Master's or Bachelor's degree in engineering. The 29 "Added Value" codes clustered into four themes: (1) Career-related Outcomes; (2) Resulting Attributes or Skills; (3) Positive Responses from Others; and (4) Neutral Value or Limitations of Getting an Engineering PhD.

\section{Career-related outcomes}

The added value associated with an engineering $\mathrm{PhD}$ holder's career is displayed in a variety of outcomes. As it relates to starting a career upon graduation, this may mean starting at a higher position than they could have without the credential or having the credentials to satisfy the qualifications for a new position. Some participants mentioned being at a "different slot within the hierarchy in the company" and having higher starting salaries as a result of earning a $\mathrm{PhD}$.

The engineering PhD also leads to access to more professional opportunities and more leadership positions. Fiscal benefits are also included in the theme of career-related outcomes. Lastly, the freedom to pursue funding to execute ideas and the flexibility to design their careers are also examples of the added value of earning an engineering $\mathrm{PhD}$.

One biomedical engineer who works in industry put it this way:

Even though the work that I'm doing right now isn't exactly in the field I study, I could transition back into doing biomedical research. ... I could also transition back into academia because I do have a PhD. So I think it gives me more options for long-term career aspirations.

Most participants stated that the career-related added value of earning an engineering $\mathrm{PhD}$ will vary depending on someone's career goal.

\section{Resulting attributes or skills}

The added value of an engineering $\mathrm{PhD}$ also includes the attributes and skills that result from the pursuit. These attributes and skills relate to ways of thinking and tasks associated with careerrelated outcomes that were discussed previously. Ways of thinking may include developing deeper understandings of fundamental concepts, unique ways of thinking, problem-solving skills, skills for learning quickly, skills that span an entire career (i.e., lifelong learning). The intellectual fulfillment that someone may experience as a result of earning an engineering $\mathrm{PhD}$ is also part of this added value. 
The ability to communicate effectively is another added value. An engineer working in industry highlighted that the technical writing skills that come with pursuing a $\mathrm{PhD}$ are at "a different level beyond a Master's." Additionally, participants perceived that they were prepared for faculty positions upon receipt of the degree. The participants who have only worked in academia mentioned skills such as teaching, serving on committees, and conducting research when describing the preparation they received during their doctoral educations. Another added value is the ability to impact young scholars, which is not reserved to academic contexts. Additionally, participants talked about the pursuit and receipt of the engineering $\mathrm{PhD}$ as a process by which individuals learn about themselves. Examples of this include learning one's organizational skills, learning styles, and individual ways of thinking. Moreover, the pursuit and receipt of the engineering $\mathrm{PhD}$ also builds confidence and persistence in the individual. For some, it is where they established their engineering identities. One chemical engineer, who is now a department chair, noted:

Oh I think it's huge. I mean I think that as a person who has all three [Bachelors, Masters, and $\mathrm{PhD}$ ] degrees, I see the difference in the different levels. I think that umm, really the education I got from the Bachelor's degree was something that allowed me to do some interesting things. But I don't think I really found my way as an engineer until I went to graduate school.

\section{Positive responses from others}

Participants spoke about changes in how others responded to them after they earned their engineering $\mathrm{PhD}$ as an added value. For many, the engineering PhD gave them credibility and prestige. One industry participant spoke about an experience she had when traveling internationally on a project:

When I went to Korea ... my project manager who I was traveling with said, with the PhD after your name because that in a lot of different cultures that's very significant. And so I found that when I traveled there, the reality, you know they didn't know me too well, but they kind of gave me a certain level of respect.

Engineering PhD holders in both industry and academia spoke often about being seen as experts in their fields. Evidence of this might include having colleagues ask them for their input on specific aspects of a project or being invited to share their research insights on a panel of experts.

\section{Neutral Value or Limitations of an Engineering PhD}

Although valuable, some participants cited the neutral value or some of the limitations of earning an engineering PhD. Only one participant reported "no added value" of earning an engineering $\mathrm{PhD}$. Subsequently, the participant went on to explain ways in which it does add value along with some of the limitations of having an engineering $\mathrm{PhD}$. As it relates to limitations of possessing an engineering $\mathrm{PhD}$, one participant working in industry discussed perceptions colleagues had of the engineering $\mathrm{PhD}$ holders in their work environment: "Some people misperceive them as being really, really smart, but not really knowing how to move theory into something that's practical." Another person said, "Sometimes people think too, that [since] you have a $\mathrm{PhD}$ you might be a little bit more introverted and not really be able to express yourself as well as others."

Another participant talked about $\mathrm{PhD}$ holders who struggle to translate their research for nontechnical audiences and to a level of abstraction that is meaningful to others:

So, one of the things that I think hampers a lot of the engineers, and actually even the PhD scientists as well, is they're so enthused about what they've got, what they've learned, that every last little detail is of equal importance to them. And, they need to learn that they need to be able to separate out those things that are of vital significance 
London, Cox, Ahn, Branch, Torres-Ayala, Zephirin, \& Zhu

versus merely interesting. And understanding which of those elements go into that twominute speech versus the two-hour discussion.

\section{Discussion}

The results of this study indicate that there is an overlap between the Motivation and Added Value themes. In both instances there are themes related to the recipients' future careers (i.e., Engineering $\mathrm{PhD}$ Needed for Career Aspirations \& Career Related Outcomes). Furthermore, the influence and responses of others are significant for both motivation and added value. This implies that one of the best ways to increase the numbers of students pursuing PhDs might be to engage them actively with mentors and others who talk to them about earning $\mathrm{PhDs}$ in engineering. Similarly, intrinsic factors drove some participants to pursue the engineering $\mathrm{PhD}$, and many of them speak highly of the attributes and skills that result from obtaining the degree. The research findings also reveal that what motivates someone to get an engineering $\mathrm{PhD}$ may overlap with and sometimes differ from what they get out of the experience. The implication of this finding is that there may be a need for more recruitment messages indicating that earning an engineering $\mathrm{PhD}$ can lead to more benefits and outcomes than what is intended and/or perceived from an outsider's perspective.

In many ways, the findings of this study converge and diverge from existing literature on motivations for earning a $\mathrm{PhD}$, in general, and an engineering $\mathrm{PhD}$, specifically. In the literature, there were five main themes associated with motivations for pursuing a PhD: career development, interest in a topic or research, personal motives, prior experiences, influenced by someone, and other miscellaneous factors. The findings of this study indicate that the motivations for pursuing an engineering $\mathrm{PhD}$ are consistent with what motivates people in other disciplines to pursue a $\mathrm{PhD}$. More specifically, there is a direct alignment between career development motives discussed in the literature and engineering $\mathrm{PhD}$ holders' motivations related to career aspirations (Baytiyeh \& Naja, 2011a; Brailsford, 2010; Churchill \& Sanders, 2007; Donnelly, 2011; Leonard et al., 2005; NSF, 2012a; Peters \& Daly, 2013; Simon, 2010). There is also a connection between motivations to get a $\mathrm{PhD}$ because of interest in a topic or research or personal motives and engineering PhDs' intrinsic motivations. Moreover, existing literature talks about motivations to get a $\mathrm{PhD}$ as a result of the influence of someone (Simon, 2010), and engineering PhDs in this study talked about this same influence as a motivating factor.

Two motivational factors that were not well grounded in existing literature map well to the findings of this study. One, education PhD holders discussed a motivation to acquire the named degree (Leonard et al., 2005). This idea did not show up among the motivations, but it does relate to the added value of possessing an engineering $\mathrm{PhD}$. To some extent, this aligns with the responses from others that engineering $\mathrm{PhDs}$ talked about as one of the added values of possessing an engineering $\mathrm{PhD}$. In this case, responses from others include the respect and credibility that comes with being called a "PhD". The second motivational factor that seemed somewhat anecdotal in the literature fits well with findings of this study. In particular, NSF's Survey of Earned Doctorates cited institutions - particularly those with high research activity - as a factor that influences an individual's path to the doctorate (NSF, 2012a). One of the major themes that emerged from this analysis was that prior success in graduate school and exposure to research and similar activities was a factor that motivated engineering PhDs to earn the degree.

In the literature, the added value of a $\mathrm{PhD}$ is discussed in terms of additional skills, keen insights, new ways of thinking, and unique ways of problem solving (Lloyd-Williams, 2012). The added value theme identified in this study - namely, Resulting Skills and Attributes - is consistent with the work of Lloyd-Williams (2012). On the other hand, the other themes related to the added value of obtaining an engineering $\mathrm{PhD}$ (i.e., Career-Related Outcomes, Responses from Others, 
and Neutral Value or Limitations of Getting a $\mathrm{PhD}$ ) are a new contribution to the literature on this topic.

One of the surprising findings of this study was some participants' insight on the neutral value or limitations of having an engineering $\mathrm{PhD}$. The idea that is most salient is the need for engineering $\mathrm{PhDs}$ to communicate more effectively, especially when communicating with non-technical audiences. This finding is especially important for engineering $\mathrm{PhD}$ holders because of the types of roles they will hold upon graduation. Such roles might include teaching in formal and informal settings, mentoring, providing their expert opinions on an issue, leading a team, or starting a business. All of these roles have the potential to include mixed audiences, many of which may include people without technical backgrounds. The value of being able to communicate effectively cannot be overstated.

Related to motivations and added values across sectors, findings indicate that there are similarities and differences across occupational sectors. One similarity in motivation and added value across all sectors is the connection to research. In many instances, the passion for research motivates people to pursue an engineering $\mathrm{PhD}$, and the ability to conduct scientific work is a commonly cited added value of the pursuit. On the other hand, there are connections between motivation and added value by sector. For example, many who have worked in academia throughout their post-graduation careers were motivated to get the degree because of their academic career goals and the added value related to satisfying a requirement for the academic profession. Engineering $\mathrm{PhD}$ holders who have only worked in industry were often influenced by someone (e.g., mentors, teachers, parents, family members) to pursue doctoral studies - likely someone who had confidence in their abilities to complete doctoral studies. They also cited an added value of the $\mathrm{PhD}$ to be increased confidence. On the contrary, those who have worked in both academia and industry were often motivated by personal interest and passion for research and/or a particular topic; a deeper understanding of fundamental concepts is an added value most commonly mentioned by participants in this sector.

\section{Implications}

There are many implications of this study with three of them discussed here. One of the simplest and most practical implications of this study is a reminder that personal influence is a more powerful motivator than what may be perceived. Many engineering PhDs who participated in this study were able to recall the names or comments made by people who suggested they pursue doctoral studies. Up until that point, it was not a goal "on their radar"; but the seemingly simple act(s) and/or encouragement of an influential individual was enough to convince several participants to pursue $\mathrm{PhDs}$ in engineering. This might mean that professors identify bachelor's and master's students in their courses or research groups who they think have potential to pursue graduate education and become more intentional about engaging in conversations that encourage students to pursue doctoral studies. Such one-on-one efforts might be particularly advantageous if initiated by faculty to underrepresented students and to promising students in general who did not grow up with science, technology, engineering, or mathematics (STEM) role models. In this way, mentoring may result in students' increased confidence in their technical abilities and in their subsequent applications to engineering $\mathrm{PhD}$ programs.

A closely related implication of this work is to use the insights from engineering $\mathrm{PhDs}$ about the motivations and added value of earning an engineering $\mathrm{PhD}$ to frame recruitment initiatives. For example, many of the participants who have enjoyed post-PhD careers in industry were motivated by a passion for a technical subject. In light of this, some of engineering recruitment messages might inform students that they have opportunities to study topics that interest them in-depth during doctoral studies and that they have the potential to become the leading expert in their areas of interest. Prospective students should be informed not only of the freedom to study a particular 
area of interest but of opportunities for them to be creative in how they engage with the topic. Such messages should be communicated to students who are particularly interested and savvy in teaching and/or research.

The findings about the added value of possessing an engineering $\mathrm{PhD}$ also have implications for recruitment (among other things). For example, perspective students should be made aware of the variety of advancements that can come from the pursuit - career opportunities and flexibility, improved intellect, greater social capital, etc. Moreover, the current roles of the participants in this study are a small sample of the types of things that an engineering $\mathrm{PhD}$ can do after graduation. There is a need for more messages that increase students' awareness of the variety of career trajectories that are available to them if they earn an engineering PhD.

Furthermore, general messaging about the engineering $\mathrm{PhD}$ is important. While it is vital for universities to share what the doctoral training will be like, it is equally important for individuals in higher education to share the types of things that people can do with an engineering $\mathrm{PhD}$. By presenting this information, prospective students can make more informed decisions about their engineering career trajectories beyond the engineering $\mathrm{PhD}$.

\section{Conclusion}

In summary, engineering PhDs play a critical role in addressing societal challenges, but few young people in the U.S. are pursuing the degrees. National interests focused on increasing the number of engineers in the U.S. have been focused on undergraduates, but not as much attention has been given to graduate engineering education. Existing research on this topic has explored motivations for pursuing a $\mathrm{PhD}$ from the perspective of other disciples. This is the first empirical study that asked engineering PhD holders working in academia and industry to share their motivations for pursuing an engineering $\mathrm{PhD}$ and their perceptions of the added value of the possessing it. Findings indicate that what motivates someone to get an engineering $\mathrm{PhD}$ sometimes differs from what they get out of the experience. In some cases, the additional value associated with getting the engineering $\mathrm{PhD}$ is more than what was perceived before deciding to pursue it.

\section{Acknowledgements}

This study was supported primarily by the National Science Foundation under grant $\# 0747803$.

\section{References}

Ahn, B, Cox, M, London, J, \& Zhu, J. (2013). Investigating the Attributes and Expectations of Engineering Ph.D.s Working in Industry. Paper presented at the Frontiers in Education, Oklahoma City, OK.

Akay, A. (2008). A renaissance in engineering $\mathrm{PhD}$ education. European Journal of Engineering Education, 33(4), 403-413. doi: 10.1080/03043790802253475

Austin, A. E. (2003). Creating a bridge to the future: Preparing new faculty to face changing expectations in a shifting context. Review of Higher Education, 26(2), 119-144.

Baker, S., Tancred, P., \& Whitesides, S. (2002). Gender and graduate school: Engineering students confront life after the B. Eng. Journal of Engineering Education, 91(1), 41-47.

Baytiyeh, H., \& Naja, M. K. (2011a). Attitudes toward pursuing doctoral studies in dngineering. Paper presented at the American Society for Engineering Education, Vancouver, BC, Canada.

Baytiyeh, H., \& Naja, M. K. (2011b). Factors influencing the decision to enroll in an Engineering PhD Program. Paper presented at the Frontiers in Education, Rapid City, SD. 
Brailsford, I. (2010). Motives and aspirations for doctoral study: Career, personal, and inter-personal factors in the decision to embark on a history PhD. International Journal of Doctoral Studies, 5, 15-27. Retrieved from http://ijds.org/Volume5/IJDSv5p015-027Brailsford283.pdf

Churchill, H., \& Sanders, T. (2007). Getting your PhD: A practial insider's guide. Thousand Oaks, CA: Sage Publications.

Cox, M. F., London, J. S, Ahn, B., Torres-Ayala, A. T., Frazier, S., \& Cekic, O. (2011). Attributes of sucess for engineering Ph.D.s: Perspectives from academia and industry. Paper presented at the American Society for Engineering Education, Vancouver, BC, Canada.

Cox, M., Zhu, J., London, J., Ahn, B., Torres-Ayala, A. T., \& Ramane, K. D. (2012). Recommendations for promoting desirable characteristics in engineering Ph.D.s: Perspectives from industry and academia. Paper presented at the American Society for Engineering Education, San Antonio, TX.

Creswell, J. W. (2008). Educational research: Planning, conducting, and evaluating quantitative and qualitative research (3rd ed.). Upper Saddler River, NJ: Pearson Education, Inc.

Donnelly, A. E. (2011). Factors influencing career choices of underrepresented STEM PhD graduates. Paper presented at the American Society for Engineering Education, Vancouver, BC, Canada.

Fleiss, J. L. (1971). Measuring nominal scale agreement among many raters. Psychological Bulletin, 76(5), 378-382.

Gill, T. G., \& Hoppe, U. (2009). The business professional doctorate as an informing channel: A survey and analysis. International Journal of Doctoral Studies, 4, 28-57. Retrieved from http://www.ijds.org/Volume4/IJDSv4p027-057Gill267.pdf

Glaser, B. G, \& Strauss, A. (1967). The discovery of grounded theory. Chicago: Aldine.

Golde, C. M., \& Dore, T. M. (2001). At cross purposes: What the experiences of doctoral students reveal about doctoral education. Philadelphia, PA: A Report Prepared for The Pew Charitable Trusts.

Government Accountability Office. (2005). Higher education: Federal science, technology, engineering and mathematics programs and related trends, GAO-06-114. Washington, DC.

Gwet, K. (2010). Handbook of inter-rater reliability (2nd ed.). Gaitherburg, MD: Advanced Analytics, LLC.

Hoffman, M. H. W., \& Nagl, M. (2011). Skills and competences of a Doctor of Engineering. Systemics, Cybernetics and Informatics, 9(6), 75-80.

Leonard, D., Becker, R., \& Coate, K. (2005). To prove myself at the highest level: The benefits of doctoral study. Higher Education Research \& Development, 24(2), 135-149.

Lloyd-Williams, P. (2012). 'Taking it back to the office': A practioner perspective of the value of a PhD. Teaching Public Administration, 30(1), 54-58.

Mason, M. M. (2012). Motivation, satisfaction, and innate psychological needs. International Journal of Doctoral Studies, 7, 259-277. Retrieved from http://ijds.org/Volume7/IJDSv7p259-277Mason0345.pdf

National Academy of Engineering. (2005). Engineering research and america's future: Meeting the challenges of a global economy. Washington, DC: The National Academies Press.

National Academy of Engineering. (2008a). Changing the conversation. Washington, DC: National Academies Press.

National Academy of Engineering. (2008b). Grand challenges for engineering. Washington DC: The National Academies Press.

National Academy of Engineering. (2010). Rising above the gathering storm, revisited: Rapidly approaching category 5. The National Academies Press.

National Academy of Engineering. (2013). Messaging for engineering: From research to action: The National Academies Press. 
National Research Council. (2007). Rising above the gathering storm: Energizing and employing America for a brighter economic future. Washington, DC: The National Academies Press.

Nerad, M., Aanerud, R., \& Cerny, J. (2004). "So you want to become a professor!": Lessons from the PhD Ten Years Later study. In D. Wulff \& A. Austin (Eds.), Paths to the professoriate: Stategies for enriching the preparation of future faculty. San Francisco: Jossey-Bass.

Nerad, M, \& Cerny, J. (2000). Improving doctoral education: recommendations from the PhDs - Ten Years Later study. Council of Graduate Schools Communicator, 33(6).

NSF. (2012a). Doctorate recipients from U.S. universities: What influences the path to the doctorate? Retrieved from http://www.nsf.gov/statistics/sed/digest/2011/theme3.cfm

NSF. (2012b). Employment sector of doctorate recipients with definite postgraduation U.S. employment commitments, by broad field of study: Selected years, 1991-2011. Retrieved September 11, 2013 http://www.nsf.gov/statistics/sed/2011/pdf/tab46.pdf

NSF. (2012c). Science and Engineering Doctorates: 2011. Retrieved September 11, 2013 http://www.nsf.gov/statistics/sed/2011/pdf/tab18.pdf

NSF. (2012d). Science and Engineering Doctorates: 2011. Retrieved August 5, 2013, from http://www.nsf.gov/statistics/sed/digest/2011/theme2.cfm - 1

Nyquist, J. D., \& Woodford, B. J. (2000). Re-envisioning the PhD: What concerns do we have? Seattle, WA: University of Washington, Center for Instructional Development and Research.

Nyquist, J. D., Woodford, B. J., \& Rogers, D. L. (2004). Re-envisioning the PhD: A challenge for the twenty-first century. In D. Wulff \& A. Austin (Eds.), Paths to the professoriate: Strategies for enriching the preparation of future faculty. San Francisco: Jossey-Bass.

Peters, D. L., \& Daly, S. R. (2013). Returning to graduate school: Expectations of success, values of the degree, and managing the costs. Journal of Engineering Education, 102(2), 244-268.

President's Council of Advisors on Science and Technology (Producer). (2010). Prepare and inspire: K-12 education in Science, Technology, Engineering and Math (STEM) for America's future. Retrieved from http://www.whitehouse.gov/sites/default/files/microsites/ostp/pcast-stem-ed-final.pdf

President's Council of Advisors on Science and Technology (Producer). (2012). Engage to Excel: Producing one million additional college graduates with degrees in Science, Technology, Engineering, and Mathematics. Retrieved from http://www.whitehouse.gov/sites/default/files/microsites/ostp/pcastengage-to-excel-final_2-25-12.pdf

Ramirez, E. (2013). Examining Latinos/as' graduate school choice process: An intersectionality perspective. Journal of Hispanic Higher Education, 12(1), 23-36.

Saldana, J. (2013). The coding manual for qualitative researchers (2nd ed.). Washington DC: Sage Publications.

Salmon, P. (1992). Achieving a PhD: Ten students' experience. Stylus Publishing, Inc.: Sterling, VA.

Simon, T. (2010). The road less traveled: Exploring factors that influence African Americans to pursue and complete doctoral degrees in Engineering and Applied Science disciplines. Paper presented at the American Society for Engineering Education, Louisville, KY.

Spaulding, L. S., \& Rockinson-Szapkiw, A. J. (2012). Hearing their voices: Factors doctoral candidates attribute to their persistence. International Journal of Doctoral Studies, 7, 199-219. Retrieved from http://ijds.org/Volume7/IJDSv7p199-219Spaulding334.pdf

Tinto, V., \& Clewell, B. C. (1997). Studying doctoral persistence. Background paper for SRS/Professional society workshop on graduate student attrition. Arlington, VA: National Science Foundation.

U.S. Census Bureau. (2012). Educational attainment of the population 18 Years and over, by age, sex, race, and Hispanic origin: 2012. Retrieved from http://www.census.gov/hhes/socdemo/education/data/cps/2012/tables.html 
Wao, H.O., \& Onwuegbuzie, A. J. (2011). A mixed research investigation of factors related to time to the Doctorate in Education. International Journal of Doctoral Studies, 6, 115-134. Retrieved from http://ijds.org/Volume6/IJDSv6p115-134Wao320.pdf

Watson, J., \& Lyons, J. (2011a). Aligning academic preparations of engineering PhD programs with the needs of industry. International Journal of Engineering Education, 27(6), 1394-1411.

Watson, J., \& Lyons, J. S. (2011b). A survey of essential skills for Ph.D. engineers in industry. Paper presented at the Survey of Essential Skills for Ph.D. Engineers in Industry, Vancouver, BC, Canada.

Watson, J., \& Lyons, J. S. (2012). Investigation of the work environment of engineering Ph.D.s in the United States. Paper presented at the American Society for Engineering Education, San Antonio, TX.

\section{Biographies}

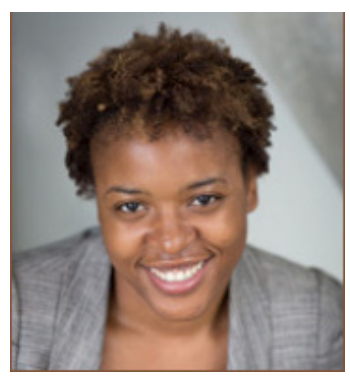

Jeremi S. London, PhD, recently completed doctoral studies in the School of Engineering Education at Purdue University. She is near completion of an internship project with the National Science Foundation, and will soon begin as a postdoctoral researcher at Arizona State University. She holds BS and MS degrees in Industrial Engineering from Purdue as well. She is a mixed methods researcher with three primary research interests in: education policy issues surrounding cyberlearning in undergraduate science, technology, engineering, and mathematics (STEM) education; characterizing and measuring the impact of federal investments in STEM education research; and applications of simulation \& modeling tools to conduct evaluations of undergraduate engineering education curriculum.

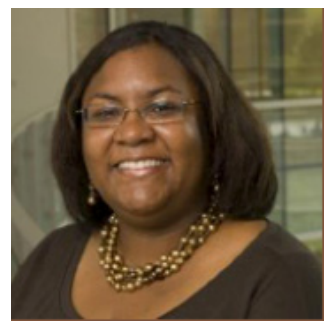

Monica F. Cox, PhD, is an Associate Professor in the School of Engineering Education at Purdue University and is the Inaugural Director of the Engineering Leadership Minor. She obtained a BS in mathematics from Spelman College, a MS in industrial engineering from the University of Alabama, and a PhD in Leadership and Policy Studies from Peabody College of Vanderbilt University. Teaching interests relate to the professional development of graduate engineering students and to leadership, policy, and change in science, technology, engineering, and mathematics education. Primary research projects explore the preparation of engineering doctoral students for careers in academia and industry and the development of engineering education assessment tools. She is a National Science Foundation Faculty Early Career (CAREER) award winner and is a recipient of a Presidential Early Career Award for Scientists and Engineers (PECASE).

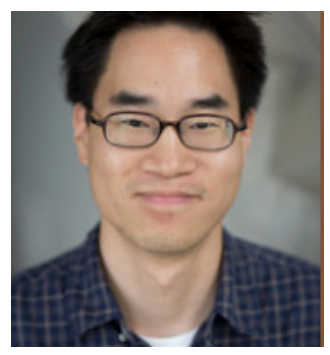

Benjamin Ahn, PhD, recently completed his doctoral studies in the School of Engineering Education at Purdue University, and will soon begin a position as a postdoctoral researcher at the Massachusetts Institute of Technology (MIT). His research interests include identifying effective mentoring skills in undergraduate research settings, exploring leadership development of undergraduates, and determining professional engineering practices in universities and industries. Benjamin's research has been strongly motivated by challenging, exciting, and inspiring experiences he has had as a teaching assistant in first-year engineering classes and as a graduate assistant for Purdue's Summer Undergraduate Research Fellowships (SURF) program and Purdue's Minority Engineering Program (MEP). 


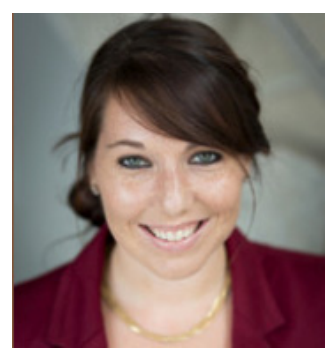

Sara E. Branch, PhD, recently completed her doctoral studies in the Department of Psychological Sciences at Purdue University, and will soon begin a position as an Assistant Professor at Hobart and William Smith Colleges. She received her BA in Psychology from the University of Portland and a M.S. in Psychology (Social) from Purdue University. Her research focuses broadly on interests and motivation. She has collaborated with the School of Engineering Education at Purdue to study how individual differences in Person and Thing Orientations influence student interest in science, technology, engineering, and mathematics (STEM) fields.

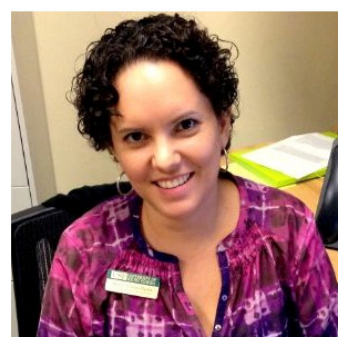

Ana Torres, $\mathrm{PhD}$, is an Assistant Director of Academic Success Center at the University of South Florida (USF) where she oversees the learning support services provided in the SMART Lab. She holds a PhD degree in Higher Education-College Teaching from USF, a BS degree in Computer Engineering from the University of Puerto Rico, Mayaguez, and an M.Eng. degree in Computer and Systems Engineering from Rensselear Polytechnic Institute. Her research interests include the scholarship of teaching and learning in engineering education, faculty development, and underrepresented student success in science, engineering, technology, and mathematics (STEM).

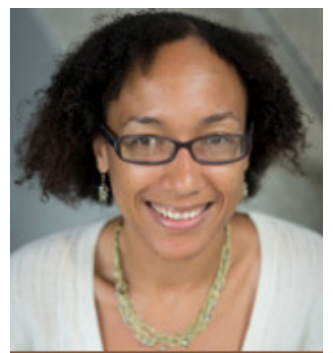

Tasha Zephirin is a $\mathrm{PhD}$ student in the School of Engineering Education at Purdue University. She is a Trainee in the National Science Foundation sponsored Integrative Graduate Education and Research Training in Magnetic and Nanostructured Materials (IGERT-MNM) program-a collaborative effort between Purdue University, Cornell University and Norfolk State University. Her research interests include incorporating insights from educational research, international and global education to best advise the development and assessment of STEM education programs to diverse audiences across the education continuum (e.g. community members, K-12 students, undergraduate students, graduate students, and industry professionals) in different international contexts.

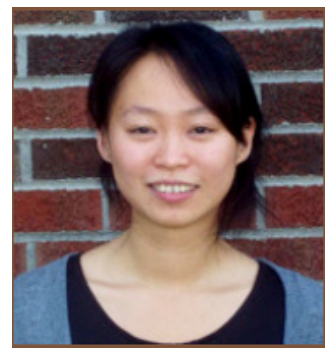

Jiabin Zhu, PhD, is an Assistant Professor at the Graduate School of Education in Shanghai Jiao Tong University, China. She obtained a BS in Physics from East China Normal University, a MS in Optics from Chinese Academy of Sciences, a second M.S. in Biomedical Engineering and a PhD in Engineering Education from Purdue University. Her primary research interests relate to the development of engineering students' professional skills, the assessment of teaching and learning in engineering, and the cognitive development of graduate and undergraduate students. 